\title{
The Importance of Scientific Tests In Masonry Heritage Building Conservation In Malaysia
}

\author{
Tan Chin Ling ${ }^{1, *}$, and A Ghafar Ahmad ${ }^{1}$ \\ ${ }^{1}$ School of Housing, Building and Planning, Universiti Sains Malaysia, 11800 Penang, Malaysia
}

\begin{abstract}
Since the Portuguese era in Malacca in the $16^{\text {th }}$ century, many authentic colonial heritage buildings were built in Malacca and other parts of Malaysia, most of which were masonry structural buildings. After Melaka and George Town received recognition from UNESCO as World Heritage Sites on $7^{\text {th }}$ July 2008 , heritage building conservation in Malaysia has attracted serious attention from various parties. Since the establishment of the National Heritage Department under the National Heritage Act 2005 (Act 645) on 1 March 2006, the implementation of scientific tests in heritage building conservation practice in Malaysia has been encouraged and recommended by the Department. However, scientific tests are normally only conducted in conservation works of National Heritage buildings and some Category I heritage buildings, but not made compulsory for all heritage buildings conservation projects in Malaysia. This paper is based on a research carried out to study the scientific tests conducted in masonry heritage building as part of conservation practice in Malaysia. The research findings revealed that scientific tests such as X-ray fluorescence test, ion chromatography test, moisture test and Schmidt hammer rebound test are important for masonry heritage building conservation in Malaysia. The basic guidelines to conduct the scientific tests derived from the research findings will be able to enhance the current practice in conserving masonry heritage buildings in Malaysia.
\end{abstract}

\section{Introduction}

Several studies related to scientific tests such as X-ray fluorescence test, ion chromatography test, moisture \& dampness test and Schmidt hammer rebound test in heritage building conservation have been carried out in Europe, Australia, Malaysia and other countries. A Ghafar and Haris Fadzilah. (2010) revealed that salt attack and rising dampness are the common building defects in heritage buildings in Penang, Malaysia. The paper stated that the existence of mineral salts may weaken the building components. The three types of destructive soluble salts which commonly found in the masonry wall of heritage buildings were chlorides $(\mathrm{Cl})$, nitrates $\left(\mathrm{NO}_{3}\right)$ and sulphates $\left(\mathrm{SO}_{4}\right)$. These soluble salts can be detected by conducting ion chromatography test. ${ }^{[1]}$ Paulo Lourenco et al.(2014) revealed the possible causes of damage and the usage of scientific expert systems in building defects diagnosis by understanding the chemical, physical and properties of mortar, brick and masonry. ${ }^{[2]}$ Nadia Bianco et al. (2013) reported the evaluation of the performance of the mortar by tracing on the basis of the results of the analyses and tests. In the other words, scientific test is an effective tool to diagnosis building defect and building material performance. ${ }^{[3]}$ A Ghafar Ahmad et al. (2005) stated that several scientific tests such as x-ray fluorescence test, salt level test, Schmidt hammer rebound test and paint colour scheme analysis were carried out in Old City Hall, George Town building conservation project to safeguard its authenticity and historical value. ${ }^{[4]}$ These papers showed that scientific tests play an important role in heritage building conservation. In the Technical Guide of Salt Attack and Rising Damp, a guide to salt damp in historic and older buildings, David Young (2008) found that accurate diagnosis is critically important where there is no substitute for a thorough understanding of a building's behavior and its response to changes over time. It only can be done by conducting systematic scientific tests. ${ }^{[5]}$

\section{Methodology}

The masonry heritage building which is the major typology of heritage building in Malaysia has been selected as research building type for this study. The data was collected from several literature reviews and documents such as 
final conservation reports and scientific test reports conducted in masonry heritage building conservation projects in Malaysia. The data was compiled and analysed to reveal the importance of the scientific test in masonry heritage building conservation. Furthermore, the basic guidelines to conduct the scientific tests were derived from the research findings with the aim to enhance current practices.

\section{Discussion and Findings}

\subsection{Significance of Risk in Building Diagnostics}

Ana Pereira R. and Douglas J. (2008) stated that all interventions in the built environment incur risks. ${ }^{[6]}$ The word 'risk' has been defined as the combination of possibility of an event and its consequence. ${ }^{[7]}$ Hence, in heritage building conservation, application of appropriate conservation methods or techniques is the key towards ensuring a successful conservation project. Therefore, the decision making tool in heritage building conservation projects should be evidence-based practice involving the application of scientific tests. Evidence is something that is visible, measurable and recordable. ${ }^{[8]}$ Evidence is the facts, information and data that answers the question regarding building failures. The evidence can be observed directly on site or revealed by conducting scientific tests. The quantity or quality of evidence is related to the significance of risk in building diagnostics. For instance, no information may lead to uncertainty, while comprehensive information may lead to certainty. ${ }^{[9]}$ According to Douglas J. (2013), "risk always involves an element of uncertainty, but uncertainty does not always involve risk." ${ }^{[10]}$

\subsection{Scientific Methods}

According to the Oxford Dictionaries Online, scientific method is defined as "A method of procedure that has characterized natural science since the $17^{\text {th }}$ century, consisting in systematic observation, measurement, and experiment, and the formulation, testing, and modification of hypotheses. ${ }^{[11]}$ In heritage building conservation, building conservators or architects may require the expertise of specialists to detect or analyse the building defects. These specialists such as chemists or material engineers will conduct scientific methods to assist in building diagnostics. There are several scientific methods or tests to assist building diagnostics, including destructive and nondestructive tests.

\subsection{X-ray Fluorescence (XRF) Test}

X-ray fluorescence (XRF) test refers to "the emission of characteristic "secondary" (or fluorescent) X-rays from a material that has been excited by bombarding with high-energy $x$-rays or gamma rays." ${ }^{[12]}$ It is a powerful quantitative and qualitative analytical tool for elemental analysis of materials such as plaster and mortar. It is used to analyse major elements such as silicon dioxide $\left(\mathrm{SiO}_{2}\right)$, titanium dioxide $\left(\mathrm{TiO}_{2}\right)$, aluminium oxide $\left(\mathrm{Al}_{2} \mathrm{O}_{3}\right)$, ferric oxide $\left(\mathrm{Fe}_{2} \mathrm{O}_{3}\right)$, manganese $(\mathrm{II})$ oxide $(\mathrm{MnO})$, magnesium oxide $(\mathrm{MgO})$, calcium oxide $(\mathrm{CaO})$, sodium oxide $\left(\mathrm{Na}_{2} \mathrm{O}\right)$, potassium oxide $\left(\mathrm{K}_{2} \mathrm{O}\right)$ and phosphorus pentoxide $\left(\mathrm{P}_{2} \mathrm{O}_{5}\right) \cdot{ }^{[13]}$ In masonry heritage building conservation in Malaysia, XRF test is conducted to identify the ratio of aggregate (silicon dioxide), calcium oxide and other elements.

\subsection{Ion Chromatography Test}

Ion chromatography (or ion-exchange chromatography) test is a chromatography process that separates ions and polar molecules based on their affinity to the ion ex-changer. ${ }^{[14]}$ In building conservation, ion chromatography test is usually conducted to investigate the level of salt embedded in the wall. The three types of destructive soluble salts commonly found in the masonry wall of heritage buildings are chlorides $(\mathrm{Cl})$, nitrates $\left(\mathrm{NO}_{3}\right)$ and sulphates $\left(\mathrm{SO}_{4}\right)$. These soluble salts can be detected by conducting ion chromatography test. ${ }^{[15]}$ The test is conducted in three stages which are before salt desalination treatment (before cocoon method), during salt desalination treatment (after application of first layer of cocoon poultice) and after salt desalination treatment. The samples are collected from particular spots on masonry walls by drilling at different depth (same spot): $10 \mathrm{~mm}, 20 \mathrm{~mm}$ and $40 \mathrm{~mm}$. Ion chromatography test is important to determine the effectiveness of salt desalination treatment. The minimum salt safety level is $0.5 \%$. 


\subsection{Moisture Test}

Moisture is one of the key factors of building defect. There are various instruments or devices for measuring moisture level at heritage buildings. In general, there are three most common moisture detecting devices such as electrical conductance moisture meter, the carbide 'Speedy' meter and the hygrometer. ${ }^{[16]}$ In Malaysia, moisture meters are used to detect the existence of dampness and moisture in masonry heritage building to ensure the effectiveness of the conservation works.

\subsection{Schmidt Hammer Rebound Test}

Schmidt hammer rebound test is conducted for non-destructive testing of the quality of concrete in the finished structure. This test provides an approximate indication of the compressive strength of hardened concrete. ${ }^{[17]}$ It is also used to test and analyze the compressive strength and level of porosity of wall plasters and bricks. In building conservation in Malaysia, Schmidt hammer rebound test is also used to identify the compressive strength of the new lime plaster mock ups before re-plastering. The new lime plaster mock ups should be left on the building exterior wall that is exposed to sunlight and rain water for at least one month before carrying out the Schmidt hammer rebound test.

\subsection{Function of the Scientific Tests}

Table 1. The Function of the Scientific Tests

\begin{tabular}{|c|l|l|}
\hline No. & \multicolumn{1}{|c|}{$\begin{array}{c}\text { Scientific } \\
\text { Test }\end{array}$} & \multicolumn{1}{c|}{ Purpose/ Function } \\
\hline 1 & $\begin{array}{l}\text { X-ray } \\
\text { Fluorescence } \\
\text { (XRF) Test }\end{array}$ & $\begin{array}{l}\text {-To identify the existence of the elements in a sample through elemental } \\
\text { analysis. } \\
\text {-To determine the contribution percentage of the elements in a sample. } \\
\text {-To determine the percentage or ratio of aggregate, calcium oxide and } \\
\text { other elements in the existing wall plaster and mortar. }\end{array}$ \\
\hline 2 & $\begin{array}{l}\text { Ion } \\
\text { Chromatogra } \\
\text { phy Test }\end{array}$ & $\begin{array}{l}\text {-To investigate the level of salt embedded in the wall, column and other } \\
\text { building components and elements. } \\
\text {-To determine the effectiveness of salt desalination treatment. }\end{array}$ \\
\hline 3 & $\begin{array}{l}\text { Moisture/ } \\
\text { Dampness } \\
\text { Test }\end{array}$ & $\begin{array}{l}\text {-To investigate the moisture or dampness level in the wall, column and } \\
\text { other building components and elements. }\end{array}$ \\
\hline 4 & $\begin{array}{l}\text { Schmidt } \\
\text { Hammer } \\
\text { Rebound Test }\end{array}$ & $\begin{array}{l}\text {-To test and analyze the compressive strength and level of porosity of } \\
\text { aall plasters and bricks. } \\
\text {-To determine the compressive strength of the new lime plaster mock ups } \\
\text { before re-plastering works carry out on site. }\end{array}$ \\
\hline
\end{tabular}

\subsection{The Importance of the Scientific Tests}

Scientific tests such as X-ray fluorescence (XRF) test, ion chromatography test, moisture/dampness test and Schmidt hammer rebound test are important to ensure the quality of masonry heritage building conservation from the aspects of building material composition and strength, accuracy of building diagnostics and effectiveness of conservation methods. 
Table 2. The Importance of the Scientific Tests

\begin{tabular}{|c|l|l|l|}
\hline $\begin{array}{l}\text { No } \\
\cdot\end{array}$ & \multicolumn{1}{|c|}{$\begin{array}{c}\text { Scientific } \\
\text { Test }\end{array}$} & \multicolumn{1}{|c|}{ Aspect } & Importance \\
\hline 1 & $\begin{array}{l}\text { X-ray } \\
\text { Fluorescence } \\
\text { (XRF) Test }\end{array}$ & $\begin{array}{l}\text { Building } \\
\text { material } \\
\text { composition }\end{array}$ & $\begin{array}{l}\text { To minimise the risk building defects such as cracking } \\
\text { or failure of wall lime plaster. }\end{array}$ \\
\hline 2 & $\begin{array}{l}\text { Ion } \\
\text { phromatogra } \\
\text { physt }\end{array}$ & $\begin{array}{l}\text { Effectivenes } \\
\text { s of } \\
\text { conservatio } \\
\text { n methods }\end{array}$ & $\begin{array}{l}\text { To determine the effectiveness of salt desalination } \\
\text { treatment by comparing the salt level (before and after } \\
\text { treatment). }\end{array}$ \\
\hline 3 & $\begin{array}{l}\text { Moisture/ } \\
\text { Dampness } \\
\text { Test }\end{array}$ & $\begin{array}{l}\text { Accuracy of } \\
\text { building } \\
\text { diagnostics }\end{array}$ & $\begin{array}{l}\text { To determine the areas or locations of walls, columns } \\
\text { and other building components and elements with high } \\
\text { moisture or dampness level. It is important to minimise } \\
\text { the intervention } \\
\text { in heritage building conservation. }\end{array}$ \\
\hline 4 & $\begin{array}{l}\text { Schmidt } \\
\text { Hammer } \\
\text { Rebound } \\
\text { Test }\end{array}$ & $\begin{array}{l}\text { Building } \\
\text { material } \\
\text { strength }\end{array}$ & $\begin{array}{l}\text { To ensure the quality and compressive strength of the } \\
\text { new wall plaster used for re-plastering works of } \\
\text { heritage building. }\end{array}$ \\
\hline
\end{tabular}

\subsection{Basic Guidelines to Conduct the Scientific Tests}

Table 3. Basic Guidelines to Conduct the Scientific Tests

\begin{tabular}{|c|c|c|}
\hline No. & $\begin{array}{c}\text { Scientific } \\
\text { Test }\end{array}$ & Basic Guidelines \\
\hline 1 & $\begin{array}{l}\text { X-ray } \\
\text { Fluoresce } \\
\text { nce } \\
\text { (XRF) } \\
\text { Test }\end{array}$ & $\begin{array}{l}\text {-Collect samples of the existing lime plaster or lime mortar on site. At least } \\
\text { three samples for comparison purpose. } \\
\text {-Minimum } 50 \text { gram per sample. } \\
\text {-Do not use metal or concrete made tools during the sample collection } \\
\text { process as it may affect the result. } \\
\text {-Record the location of the samples collected on the architectural drawing } \\
\text { and report for documentation purpose. } \\
\text {-Send the samples to the laboratory for testing. } \\
\text {-Analyse the test result to identify the ratio of aggregate, calcium oxide and } \\
\text { other elements for further action. }\end{array}$ \\
\hline 2 & $\begin{array}{l}\text { Ion } \\
\text { Chromato } \\
\text { graphy } \\
\text { Test }\end{array}$ & $\begin{array}{l}\text {-Collect samples from particular spots on masonry walls by drilling at } \\
\text { different depth (same spot): } 10 \mathrm{~mm}, 20 \mathrm{~mm} \text { and } 40 \mathrm{~mm} \text {. } \\
\text {-The test shall be conducted for two stages which are before and after the } \\
\text { salt desalination treatment process. } \\
\text {-Do not collect the samples during the raining day as it may affect the result. } \\
\text {-Record the location of the samples collected on the architectural drawing } \\
\text { for documentation purpose. } \\
\text {-Send the samples to the laboratory for testing. } \\
\text {-Analyse the test result to identify the level of salt embedded in the walls for } \\
\text { further action. }\end{array}$ \\
\hline 3 & $\begin{array}{l}\text { Moisture/ } \\
\text { Dampnes } \\
\text { s Test }\end{array}$ & $\begin{array}{l}\text {-Collect data of moisture/ dampness level (internal and external walls and } \\
\text { structures) with the aid of moisture meter. } \\
\text {-Mark and label the level of moisture or height of rising damp on the walls } \\
\text { and structures for reference and further action. } \\
\text {-Record the moisture/ dampness level data on the architectural drawing and } \\
\text { report for documentation purpose. } \\
\text {-Analyse the test result to identify the level of moisture/ dampness for } \\
\text { further action. }\end{array}$ \\
\hline
\end{tabular}




\begin{tabular}{|c|c|c|}
\hline 4 & $\begin{array}{l}\text { Schmidt } \\
\text { Hammer } \\
\text { Rebound } \\
\text { Test }\end{array}$ & $\begin{array}{l}\text {-The plunger of the Schmidt hammer is pressed against the spot of the } \\
\text { selected surface to be tested. } \\
\text {-Collect } 16 \text { readings in grid arrangement at a surface of } 1 \text { square foot. } \\
\text {-Note: For new plaster mock ups, the mock ups shall be left at site and } \\
\text { exposed to sunlight and rain water for at least one month before carrying out } \\
\text { the Schmidt hammer test. } \\
\text {-Calculate the mean- } \mathrm{R} \text { value, standard deviation and estimated cube } \\
\text { compressive strength }\left(\mathrm{N} / \mathrm{mm}^{2}\right) \text {. } \\
\text {-Record the compressive strength data in the report for documentation } \\
\text { purpose. } \\
\text {-Analyse the test result to identify the compressive strength of the wall } \\
\text { plasters for further action. }\end{array}$ \\
\hline
\end{tabular}

\section{Conclusion}

As heritage buildings have significant cultural and historical values to the community and country, the application of appropriate conservation methods or techniques is the key to safeguarding the nation's heritage. The decision making tool in heritage building conservation projects should be evidence-based practice as risk always involves an element of uncertainty. Hence, scientific tests such as X-ray fluorescence test, ion chromatography test, moisture/ dampness test and Schmidt hammer rebound test should be conducted in all masonry heritage building conservation projects in Malaysia to ensure the quality of masonry heritage building conservation in the aspects of building material composition and strength, accuracy of building diagnostics and effectiveness of conservation methods. Without application of the scientific tests, the quality of the masonry heritage building conservation and the cultural significance of the masonry heritage building in Malaysia will be at risk.

\section{References}

1. A. A Ghafar, A.R. Haris Fadzilah. Treatment of Salt Attack and Rising Damp on Heritage Buildings in Penang, Malaysia. J.C.D.C., 15(1), pp.93-112. (2010)

2. B. Paulo Lourenco, et al. Characterization and damage of brick masonry, Springer, Historical and Masonry Structures Group, University of Minho, Portugal. (2014)

3. N. Bianco et al. Hydraulic mortar and problems related to the suitability for restoration, J. Periodico di Mineralogia (2013), 82, 3, pp.529-542. (2013)

4. A. A Ghafar, A.R. Haris Fadzilah. Restoration and Refurbishment of Old City Hall, George Town, Penang, Malaysia, Proceedings of 2005 International Conference on Construction and Real Estate Management, 2005, Wang Yaowu eds., China Architecture and Building Press, Vol. 2, pp. 1356-1361.(2005)

5. D. Young. Technical Guide Salt Attack and Rising Damp, a guide to salt damp in historic and older buildings, Heritage Council of NSW; Heritage Victoria, Department of Planning and Community Development; South Australian Department for Environment and Heritage; Adelaide City Council. (2008)

6. R. Ana Pereira, James, D. Interventions In Built Heritage: Managing Which Risks And For Whom, CIB W070 Conference in Facilities Management, Heriot Watt University, Edinburgh, 2008, pp.25-32.(2008)

7. BSI. Risk Management vocabulary - Guidelines for use in Standards, London: British Standards Institution, Guide 73. (2002)

8. J. Douglas, Ransom, B. Understanding Building Failures. $4^{\text {th }}$ ed. Oxon: Routledge. (2013)

9. G. Bowles, JR. Kelly. Value and Risk Management, D19CV9 Course Notes for Msc. Construction Management Programme, Heriot-Watt University, Edinburgh. (2005)

10.J. Douglas, B. Ransom. Understanding Building Failures. $4^{\text {th }}$ ed. Oxon: Routledge. (2013)

11. British and World English. In: Oxford Dictionaries [online]. England: Oxford University Press. Available at https://en.oxforddictionaries.com/ definition/scientific_method (2016) [Accessed 24 October 2016].

12.Amptek.com. Overview of X-Ray Fluorescence Analysis. [online] Available at: http://amptek.com/ xrf/(2017) [Accessed on 31 March 2017].

13. K. Wirth, A. Barth. X-Ray Fluorescence (XRF), Sc. Edu. Resource Center, Carleton College, USA. (2016)

14.Wikipedia. Ion Chromatography. [online] Available at: https://en.wikipedia. org/wiki/Ion_chromato graphy (2016) [Accessed on 11 November 2016]. 
15. A. A Ghafar, A.R. Haris Fadzilah. Treatment of Salt Attack and Rising Damp on Heritage Buildings in Penang, Malaysia. J.C.D.C., 15(1), pp.93-112. (2010)

16. J. Douglas, B. Ransom. Understanding Building Failures. $4^{\text {th }}$ ed. Oxon: Routledge. (2013)

17.J. Douglas, B. Ransom. Understanding Building Failures. $4^{\text {th }}$ ed. Oxon: Routledge. (2013) 